\title{
Household cereal crop harvest and children's nutritional status in rural Burkina Faso
}

\author{
Kristine Belesova $^{1 *}$ (D), Antonio Gasparrini ${ }^{1}$, Ali Sié ${ }^{2}$, Rainer Sauerborn ${ }^{3+}$ and Paul Wilkinson ${ }^{1+}$
}

\begin{abstract}
Background: Reduction of child undernutrition is one of the Sustainable Development Goals for 2030. Achievement of this goal may be made more difficult in some settings by climate change through adverse impact on agricultural productivity. However, there is only limited quantitative evidence on the link between household crop harvests and child nutrition. We examined this link in a largely subsistence farming population in rural Burkina Faso.

Methods: Data on the middle-upper arm circumference (MUAC) of 975 children $\leq 5$ years of age, household crop yields, and other parameters were obtained from the Nouna Health and Demographic Surveillance System. Multilevel modelling was used to assess the relationship between MUAC and the household crop harvest in the year 2009 estimated in terms of kilocalories per adult equivalent per day (kcal/ae/d).

Results: Fourteen percent of children had a MUAC $<125 \mathrm{~mm}$ (a value indicative of acute undernutrition). The relationship between MUAC and annual household food energy production adjusted for age, sex, month of MUAC measurement, household wealth, whether a household member had a non-agricultural occupation, garden produce, village infrastructure and market presence, suggested a decline in MUAC below around $3000 \mathrm{kcal} / \mathrm{ae} / \mathrm{d}$. The mean MUAC was $2.49(95 \% \mathrm{Cl} 0.45,4.52) \mathrm{mm}$ less at 1000 than at $3000 \mathrm{kcal} / \mathrm{ae} / \mathrm{d}$.

Conclusions: Low per capita household crop production is associated with poorer nutritional status of children in a rural farming population in Burkina Faso. This and similar populations may thus be vulnerable to the adverse effects of weather on agricultural harvest, especially in the context of climate change.
\end{abstract}

Keywords: Climate change, Malnutrition, Undernutrition, MUAC, Agriculture, Crops, Food security, Children's health, Environmental epidemiology

\section{Background}

Reducing child undernutrition and hunger is at the top of the global development agenda. It is the primary objective of the Sustainable Development Goal (SDG) No. 2 (Target 2: "by 2030 end all forms of malnutrition, including achieving by 2025 the internationally agreed targets on stunting and wasting in children under five years of age [..]" [1]) and is reflected in the policy agendas of many development agencies [2]. Malnutrition is estimated to be responsible for over a fifth of the global

\footnotetext{
* Correspondence: kristine.belesova@lshtm.ac.uk

${ }^{\dagger}$ Equal contributors

'Department of Social and Environmental Health Research, London School of Hygiene \& Tropical Medicine, 15-17 Tavistock Place, London WC1H 9SH, UK

Full list of author information is available at the end of the article
}

disease burden in children under five years of age [3, 4] and for $45 \%$ of the 5.9 million deaths in children under five in 2015 [5]. Legacy effects of childhood undernutrition may also continue into adulthood. Adults undernourished in childhood are more susceptible to infectious [6] and chronic disease [7], have lower economic productivity [8], and are more likely to have compromised cognitive development [9].

While the proportion of undernourished children in developing regions dropped from $23.3 \%$ in $1990-1992$ to $12.9 \%$ in 2014-2016, the rate of improvement over time has been slowing [10]. Climate change impacts on agricultural productivity may further challenge the achievement of SDG 2. Some analyses suggest that, in 
some settings, it could even lead to the reversal of the recent trend of decreasing undernutrition [11-16].

Household food security, a key determinant of children's nutritional status [4], is widely recognised to have four key dimensions: food availability (sufficient quantity of food of adequate quality), food access (adequate resources to acquire appropriate foods), utilization (sufficient nutrient and energy intake, resulting from appropriate food preparation, diet, intra-household food distribution, feeding practices, good care), and stability (access to adequate food at all times) $[17,18]$. In subsistence farming populations the agricultural harvest is both a source of food and of income for food purchases [19], yet its yield may vary appreciably because of variations in weather and other factors. Such populations therefore have potential vulnerability in relation to at least three of the four pillars of food security: food availability, access, and stability.

What is unclear, however, is the degree to which reduced household crop yields result in compromised nutrition. Studies in different settings provide differing results on the association of children's nutritional status with household food crop production [20-24], possibly reflecting effect of context-specific factors and variation in vulnerability across study populations (e.g., previously suggested to differ by the level of income [25-27], diversity of the cultivated crops [28, 29], gender [30], and age [24, 31]).

In this paper we report a study examining the relationship between children's nutritional status, measured by middle-upper arm circumference (MUAC), and household cereal crop production in a largely subsistence farming population of rural Burkina Faso.

\section{Methods}

\section{Study area and population}

Burkina Faso is a land-locked low-income country in West Africa, which in 2009 was ranked $6^{\text {th }}$ from bottom in terms of the Human Development Index [32]. In 2009 $46.7 \%$ of the population lived below the poverty line of US $\$ 1.25$ per person per day. $73.5 \%$ of the population is rural and relies on rain-fed agriculture [33].

The study was conducted within the population of the Nouna Health and Demographic Surveillance System (HDSS) in the Kossi province of Western Burkina Faso (Fig. 1), which has been surveyed by the Centre de Recherche en Santé de Nouna (CRSN) since 1992. The Kossi province is classified as a dry orchard savannah, and receives on average $685 \mathrm{~mm}$ of rainfall per year $[34,35]$. The single agricultural production

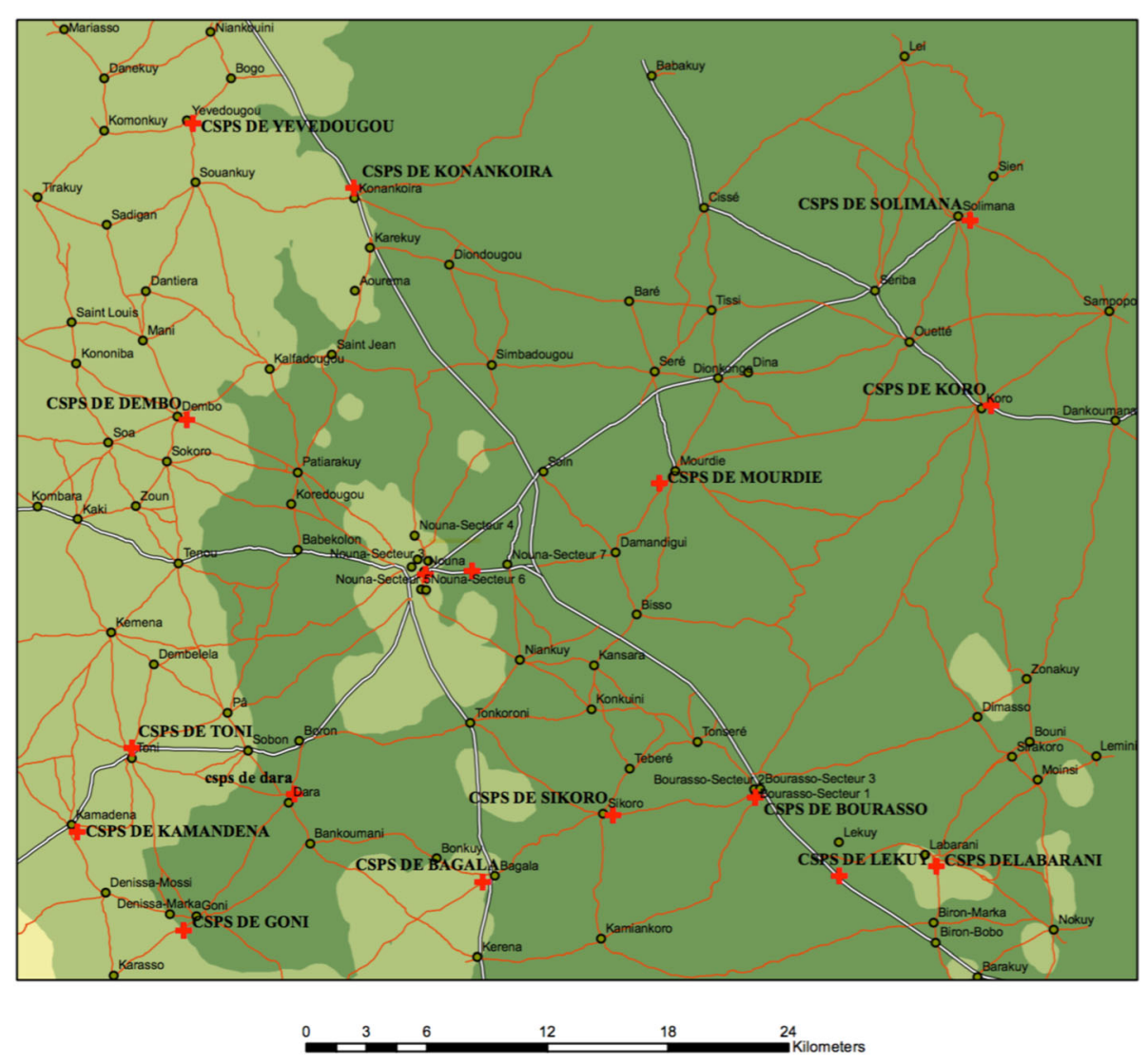

Fig. 1 Map of Nouna HDSS villages 
season lasts during the rainy season starting in June and ending in October [35]. Agricultural productivity in the Kossi province in the year of study (2009/10) was close to the average for the past 30 years. Cereals constitute $72.2 \%$ of the average daily kilocalorie (kcal) consumption in the country as a whole [36], while other food groups contribute much smaller proportions: vegetables $0.44 \%$, meat $3.18 \%$, and fish $3.45 \%$ [36].

The Nouna HDSS population almost exclusively relies on rain-fed crop produce [34, 35, 37]. Ninety-eight per cent of the population cultivate crops for food, and in most cases at levels no greater than required to meet household needs. The main food crops cultivated are millet, sorghum, fonio, maize, and rice. Farmers also grow cotton, sesame, and peanuts. Although here these three are referred to as cash crops, they are mostly gown to meet day-to-day household expenses (e.g., health care and schooling fees) from small scale sales. Sesame and peanuts can also serve as food for the household.

Here we follow the Nouna HDSS definition of a household as a socio-economic unit whose members are usually, but not necessarily, related by family ties; household members live together, share resources, and jointly meet their food and other vital needs under the authority of a single person, referred to as the head of the household [38]. The head of the household oversees agricultural activities undertaken by household members in the crop fields. Crop cultivation and harvest are mostly performed by men. In some households women may participate in selected stages of agricultural work, such as sowing and weeding. Women frequently maintain gardens where they cultivate vegetables, fruit, and herbs. Women are also responsible for grain processing, food preparation, and sales of their garden produce and food products.

Previous studies indicate high levels of child undernutrition in the Nouna HDSS population. In a sample of 460 children 6-31 months of age taken in June 2009 $35 \%$ were underweight (weight-for-age $\mathrm{z}$-score $<-2$ standard deviations (SD)), 30\% stunted (length-for-age zscore $<-2 \mathrm{SD}$ ), and 26\% had wasting (weight-for-length $\mathrm{z}$-score $<-2 \mathrm{SD}$ ) [39]. The mean MUAC in this sample was $140 \mathrm{~mm}$ with the standard deviation of $12 \mathrm{~mm}$ [39].

\section{Study sample}

The study was of children aged $0-5$ years who had undergone routine measurement of MUAC as part of the HDSS survey protocol in the year 2010. Such measurements were made in 604 households (5.83\% of all 10,364 households in the Nouna HDSS population). We selected for our analysis the 545 households (containing 975 children $\leq 5$ years in 52 villages in the Nouna HDSS area and Nouna town) that were involved in food and/or cash crop production. Although these households were not selected by random sampling, inclusion of households in the MUAC measurement survey was non-selective with regard to household characteristics, and the children $\leq 5$ years in our sample have similar demographic and socioeconomic characteristics to those of children $\leq 5$ years in the wider population, except with regard to age (Additional file 1: Table S1). The MUAC measurement protocol specifically targeted infants $<6$ months, who are therefore substantially over-represented in the sample.

\section{Data}

The data assembled for our analyses were as follows:

\section{Middle upper arm circumference (MUAC) - the main} outcome variable

We used the MUAC measurements collected by the CRSN survey team between March and August 2010. MUAC values greater than 5 standard deviations of the mean (i.e., outside the range 67 to $218 \mathrm{~mm}$ ) were considered implausible and excluded from analysis [40-42]. MUAC is a commonly used anthropometric measure indicative of children's short-term nutritional status and shown to be highly correlated with weight change [43]. In the age group of 6 months-5 years MUAC values $<125 \mathrm{~mm}$ are commonly interpreted as indicative of moderate acute undernutrition and values $<115 \mathrm{~mm}$ of severe acute undernutrition [44-47].

\section{Food energy value of the household cereal crop harvest in} 2009 - the explanatory factor of primary interest

Data on the annual quantity of each food and cash crop harvested by a household in 2009 (i.e., in the year before MUAC measurements) were recorded in the HDSS socio-economic census survey. Quantities described in such terms as tin, can or charette were converted into kilograms using conversion factors provided by the CRSN. From these we computed two measures:

(1) The energy value of average daily household food cereal crop produce in kilocalories/adult equivalent/day $(\mathrm{kcal} / \mathrm{ae} / \mathrm{d})$, $\mathrm{E}_{\mathrm{f}}=\sum_{i}\left(h_{i} \times c_{i}\right) / \mathrm{ae} / 356.25$

(2) The energy value of average daily household food and cash crops combined (kcal/ae/d),

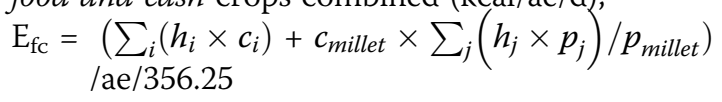

where

i - food crop: millet, maize, sorghum, fonio, rice

$\mathrm{j}$ - cash crop: cotton, peanuts, sesame

$\mathrm{h}$ - weight $(\mathrm{kg})$ of the crop

c - caloric value of $1 \mathrm{~kg}$ of the food crop i [48]

$\mathrm{p}$ - market price of $1 \mathrm{~kg}$ of peanuts, sesame, or millet in December 2009 in Nouna market prices or $1 \mathrm{~kg}$ of cotton in SOFITEX $[49,50]$

ae - number of adult equivalents (ae) in the household, using weights to reflect differences in physiological food energy needs by age and sex (a 30-60 years old male was given the weight of 1) [51, 52]. 
Thus, our main measure of food availability, $E_{f}$, was based on the cereal crop harvest and does not consider the usually modest but unquantified food energy from garden produce (vegetables, fruit, herbs etc.). (Possible differences related to the availability of garden produce were captured by adjusting for the presence of the garden produce as a binary measure in analysis - see below).

The $\mathrm{E}_{\mathrm{fc}}$ indicates the maximum potential food energy that households could acquire using all income from cash crops to purchase millet (if they chose to do so) and consuming all of their food crop harvest.

The value of ae was calculated following the method suggested by Smith and Subandoro [50], where age and sex-specific energy requirements of all household members are standardised against the energy requirements of a 30-60 years old male, but using the latest guidelines on energy and protein requirements [51, 52], and assuming moderate activity levels for household members.

The kcal value of cash crop produce was estimated as the amount that would be available if the household sold all their cash crop harvest (cotton to SOFITEX in 2009, peanuts and sesame on the Nouna market in December 2009) and used the entire income from these sales to purchase millet on the Nouna market in December 2009. Data on the price of millet, sesame, and peanuts were collected by CRSN from the Nouna town market in December 2009, and that of cotton from the cotton producer's price reports for 2009/10 provided by the Societé Burkinabé des Fibres et Textiles (SOFITEX), the biggest cotton company in Burkina Faso controlling cotton production in the Kossi province $[49,50]$.

\section{Individual, household, and village-level co-variates}

Data on child's age, sex, and month of MUAC measurement, as well as household characteristics (number of people in the household, age categories of household members, household members' occupations, housing conditions, and assets) were obtained from the HDSS surveys.

As a measure of socio-economic status we used the household wealth index of Schoeps et al. [53], re-coded into quartiles. The wealth index reflects household asset ownership (e.g., means of transport, agricultural assets, household items, such as radio, television, refrigerator, modern stove, etc.) and housing conditions (e.g., habitation type, type of roof and walls, source of lighting, type of toilet and sanitation, water source in the dry and rainy season, energy source for cooking) [53]. The choice of quartiles rather than quintiles was largely arbitrary (both are common choices) but we chose quartiles to reduce small numbers in individual strata.

We used a binary variable indicating if there is any member in the household who has a non-agricultural occupation to adjust for any differences in the association of food energy from crop production and children's MUAC related to income from other employment.
We used an indicator of whether a household had any garden produce, i.e., vegetables, fruits, and herbs, to adjust for food energy and nutrients households produced in addition to their cereal crop harvest or additional income that could have been generated from garden produce sales.

Data on village characteristics (presence of health care, education, and administrative facilities, markets, as well as the quality of roads and water wells) were obtained from the geographical information system database of the CSRN. From these we constructed a variable indicating the level of village infrastructure development, using principal components analysis of the variables just listed, and recoding the variable into quartiles. Verbal informed consent was obtained in all data collection from human subjects in agreement with the local community and with the approval of the Observational Ethics Committee and the Comité Institutionnel d'Ethique du Centre de Recherche en Santé de Nouna. Our study was also approved by the London School of Hygiene and Tropical Medicine Observational Ethics Committee.

\section{Analyses}

The main analyses were made of MUAC as a continuous measure, but for descriptive statistics MUAC was also classified using the cut off values of 125 and $115 \mathrm{~mm}$ indicative of moderate and severe acute undernutrition [45].

The association of children's nutritional status (MUAC) with the two measures of household crop harvest $\left(E_{f}\right.$ and $\left.E_{f c}\right)$ was examined using multilevel regression models, accounting for clustering at the village level. Additionally, we examined interaction of these associations with children's sex.

We used two methods of model-fitting: (i) restricted natural cubic splines (one internal knot placed at the median value of the $E_{f}$ or $E_{f c}$ [54]) to show variation in MUAC as a smooth function of $E_{f}$ or $E_{f c}$ and (ii) a piecewise linear regression model with a single change point below which MUAC was assumed to have a linear relationship with $\mathrm{E}_{\mathrm{f}}$ or $\mathrm{E}_{\mathrm{fc}}$, zero gradient was assumed above the change point. The latter models were fitted to be able to represent the relationship between MUAC and $E_{f}$ or $\mathrm{E}_{\mathrm{fc}}$ as a single regression slope. Akaike Information Criterion (AIC) and Likelihood Ratio (LR) tests were used to assess model fit including the number of knots for the restricted natural cubic spline models.

For the piecewise linear regression models we specified the change point a priori at $2900 \mathrm{kcal} / \mathrm{ae} / \mathrm{d}$, which corresponds to the recommended energy intake for a moderately active adult. For consistency, we used the same change points for piecewise models where $E_{f}$ and $\mathrm{E}_{\mathrm{fc}}$ were specified as the exposure.

All regression models were adjusted for potential confounders [55], namely: age, sex, month of MUAC 
measurement, the household wealth index, a village-level indicator of infrastructure development, and binary indicators of: participation of any household member in a non-agricultural occupation, whether the household had any garden produce, and a village-level indicator of the presence of a market. We also included an indicator of whether any of the crop types cultivated by the households in the year of study failed to provide any harvest to see if model results were sensitive to this adjustment. For transparency, we present the model results after adding selected groups of confounders until the full model with all confounders included.

Sensitivity analyses were undertaken to assess the impact of the exclusion of observations from households with high crop production values $(>8000 \mathrm{kcal} / \mathrm{ae} / \mathrm{d}$ from food crop harvest and $>15,000 \mathrm{kcal} / \mathrm{ae} / \mathrm{d}$ from food and cash crop harvest combined) - see Additional file 1: Table S2. Statistical analyses were carried out in Stata 14.1 [56].

\section{Results}

Characteristics of the study population are given in Table 1. Nearly $50 \%$ of children in our analyses were $<6$ months of age because of the survey methods which targeted

Table 1 Characteristics of households, children, and villages

\begin{tabular}{lc}
\hline Characteristics & $\begin{array}{r}\text { Mean }\left(25^{\text {th }}, 50^{\text {th }}, 75^{\text {th }} \text { cen }\right. \\
\text { or counts }(\%)\end{array}$ \\
\hline Household characteristics $(n=545)$ & $11(6,9,14)$ \\
No. of people & $8(4,7,10)$ \\
Adult equivalents & \\
Wealth & $122(23 \%)$ \\
Level 1 (poorest) & $136(25 \%)$ \\
Level 2 & $138(26 \%)$ \\
Level 3 & $104(19 \%)$ \\
Level 4 (wealthiest) & $45(8 \%)$ \\
Unclassified & $167(31 \%)$ \\
At least one member with occupation & \\
outside agriculture & $383(70 \%)$ \\
Garden produce harvested & $431(79 \%)$ \\
Cash crops harvested & $542(99 \%)$ \\
Food crops harvested & \\
Crop yield (kg/ae/year) & \\
Millet & $144(53,113,190)$ \\
Sorghum & $169(70,131,208)$ \\
Maize & $41(6,18,42)$ \\
Fonio & $14(0,5,18)$ \\
Rice & $18(0,0,24)$ \\
Cotton & $46(0,0,56)$ \\
Sesame & $37,33,68)$ \\
Peanut &
\end{tabular}

Table 1 Characteristics of households, children, and villages (Continued)

\begin{tabular}{|c|c|}
\hline \multicolumn{2}{|c|}{ Food energy equivalent (kcal/ae/d): } \\
\hline food crops & $2978(1609,2493,3769)$ \\
\hline$<2900 \mathrm{kcal} / \mathrm{ae} / \mathrm{d}$ & $321(59 \%)$ \\
\hline food \& cash crops & $4213(1965,3211,5483)$ \\
\hline$<2900 \mathrm{kcal} / \mathrm{ae} / \mathrm{d}$ & $238(44 \%)$ \\
\hline \multicolumn{2}{|c|}{ hildren's characteristics ( $n=975)$} \\
\hline \multicolumn{2}{|l|}{ Age } \\
\hline $0-<6$ months & $464(48 \%)$ \\
\hline 6 months $-<2$ years & $222(23 \%)$ \\
\hline 2 years -5 years & $289(30 \%)$ \\
\hline \multicolumn{2}{|l|}{ Sex } \\
\hline Male & $476(49 \%)$ \\
\hline Female & 499 (51\%) \\
\hline MUAC ${ }^{b}$ & $135(130,130,140)$ \\
\hline$<115 \mathrm{~mm}$ & $98(10 \%)$ \\
\hline $115-125 \mathrm{~mm}$ & $137(14 \%)$ \\
\hline \multicolumn{2}{|c|}{ Month of MUAC measurement } \\
\hline March & $131(13 \%)$ \\
\hline April & $133(14 \%)$ \\
\hline May & $208(21 \%)$ \\
\hline June & $265(27 \%)$ \\
\hline July & $139(14 \%)$ \\
\hline August & $99(10 \%)$ \\
\hline \multicolumn{2}{|c|}{ illage characteristics $(n=52)$} \\
\hline \multicolumn{2}{|l|}{ Infrastructure level } \\
\hline Level 1 (lowest) & $32(62 \%)$ \\
\hline Level 2 & $14(27 \%)$ \\
\hline Level 3 & $4(8 \%)$ \\
\hline Level 4 (highest) & $2(4 \%)$ \\
\hline Has a market & $20(37 \%)$ \\
\hline
\end{tabular}

Abbreviations: MUAC middle-upper arm circumference, kcal/ae/d kilocalories per adult equivalent per day

${ }^{a} 0$ production values present when crop was not cultivated or its harvest failed

${ }^{\mathrm{b}}$ MUAC data in the table is presented for all children included in the analyses, aged 0-5 years. Corresponding number and (\%) of children aged 6 months5 years with MUAC < $115 \mathrm{~mm}$ was $16(3 \%)$ and with MUAC 115-125 mm 51 $(10 \%)$, which indicate the proportion of severely and moderately acutely malnourished children among our study subjects

such children. The mean household size was 11 people. $31 \%$ of the households had at least one member involved in a non-agricultural occupation (such as pottery, brick making, trade, or other incomegenerating activity).

Villages varied in the level of their infrastructural development assessed by the presence/absence of administrative, educational and medical facilities, market, 


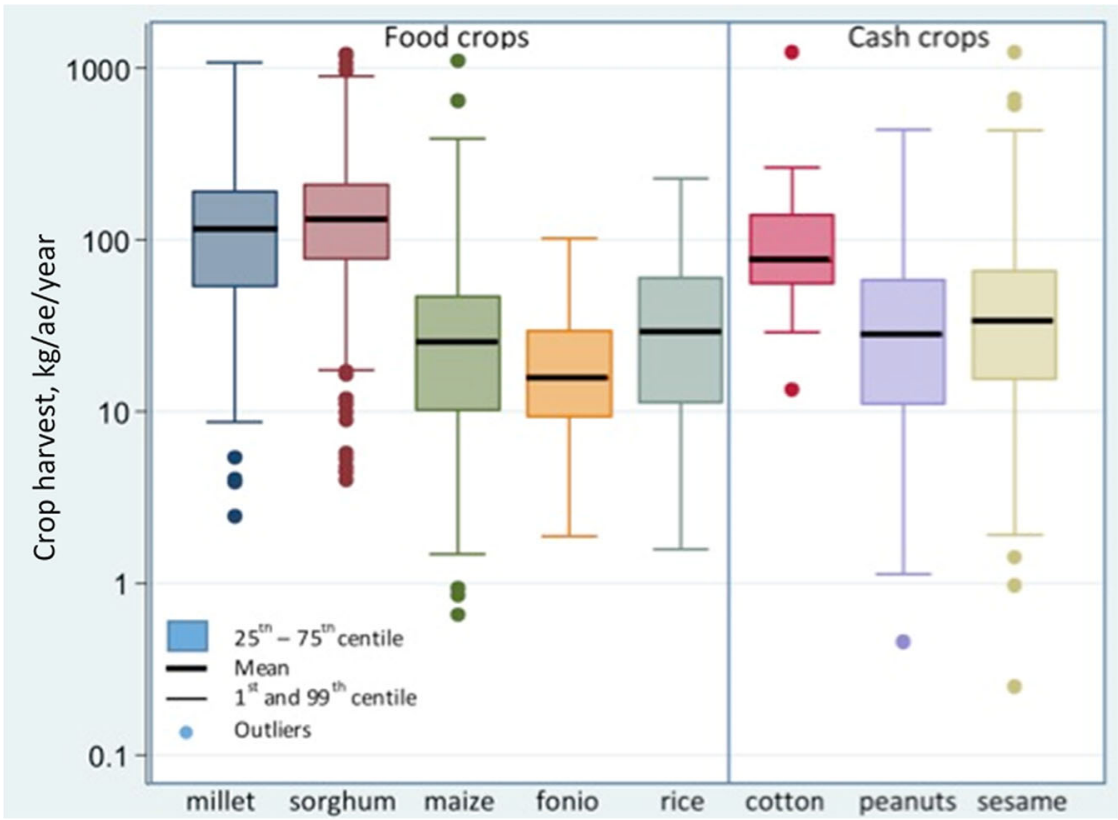

Fig. 2 The amount and variability of crop harvest across households in the year 2009. Abbreviations: kg/ae/d, kilograms per adult equivalent per day. Note 1: Results are presented on a logarithmic (to the base of 10) scale. Note 2: Households with 0 production of the crop were excluded from data presented in this figure (but included in analysis) to demonstrate harvest variability among households that managed to produce the crop

transport, and water infrastructure. A market was present in only $37 \%$ of them.

Most of the crop produce in the year 2009 was derived from millet and sorghum (Table 1; Fig. 2). The harvest size varied considerably across households and crop types (Fig. 2). $70 \%$ of the households produced some garden produce, such as vegetables, fruit, and herbs (Table 1).

Although mean food energy value of household food crop harvest exceed the recommended kcal intake of $2900 \mathrm{kcal}$ per day for moderate activity levels of our assumed adult equivalent (a 30-60 years old male) (Table 1), 62\% of the children lived in households that produced less food energy from their food crop harvest than was recommended for their households for moderate activity levels and 55\% less than recommended for light activity [51]. 32\% of the children lived in households that produced less food energy from their combined food and cash crop harvest than was recommended for their households for moderate activity and $25 \%$ less than recommended for light activity [51].

Average MUAC among children of 0-5 years of age was $135 \mathrm{~mm}$ with $10 \%$ of the children having MUAC $<115 \mathrm{~mm}$ and $14 \%$ between $115 \& 125 \mathrm{~mm}$. Among children aged 6 months -5 years, 3\% had MUAC $<115 \mathrm{~mm}$ and 10\% MUAC between 115 \& $125 \mathrm{~mm}$, indicating the proportions of severe and moderate acute undernutrition respectively (Table 1 ).

\section{Relationship between MUAC and crop harvests}

The relationships between MUAC and the two measures of annual household per capita crop harvest (kcal/ae/d), $E_{f}$ and $E_{f c}$, are shown in Fig. 3. These plots suggest that children's MUAC decreased at crop yields below around $3000 \mathrm{kcal} / \mathrm{ae} / \mathrm{d}$. The children's MUAC was 2.49 (95\% CI $0.45,4.52) \mathrm{mm}$ less at 1000 than at $3000 \mathrm{kcal} / \mathrm{ae} / \mathrm{d}$ when food energy estimates were based on cereal food crop production alone $\left(\mathrm{E}_{\mathrm{f}}\right)$, and $1.99(95 \%$ CI $0.27,3.69) \mathrm{mm}$ less when food energy estimates were based on food and cash crop production combined $\left(\mathrm{E}_{\mathrm{fc}}\right)$ (Table 2).

Piecewise linear models with a change point at $2900 \mathrm{kcal} / \mathrm{ae} / \mathrm{d}$ suggest that below $2900 \mathrm{kcal} / \mathrm{ae} / \mathrm{d}$, MUAC decreased by 1.29 (CI 95\% 0.15, 2.42) mm per $1000 \mathrm{kcal} /$ ae/d decrease in household food energy production from cereal food crops only $\left(\mathrm{E}_{\mathrm{f}}\right)$, and by 1.55 (CI 95\% 0.30, 2.81) $\mathrm{mm}$ per $1000 \mathrm{kcal} / \mathrm{ae} / \mathrm{d}$ decrease in food energy from food and cash crop harvest combined $\left(\mathrm{E}_{\mathrm{fc}}\right)$ (Table 2).

These results were largely insensitive to the exclusion of observations with high crop production values (see Additional file 1: Table S2) and the additional adjustment for crop failure (last line of Table 2).

There was no clear evidence that the decrease in MUAC with lower household food crop yields was different in boys $v s$ girls (Table $3, p=0.203$ for statistical interaction), but the point estimates of the decrease were larger in boys. Boys' MUAC was 3.81 (95\% CI 0.84, 6.77) $\mathrm{mm}$ lower at 1000 than at $3000 \mathrm{kcal} / \mathrm{ae} / \mathrm{d}$ when food 


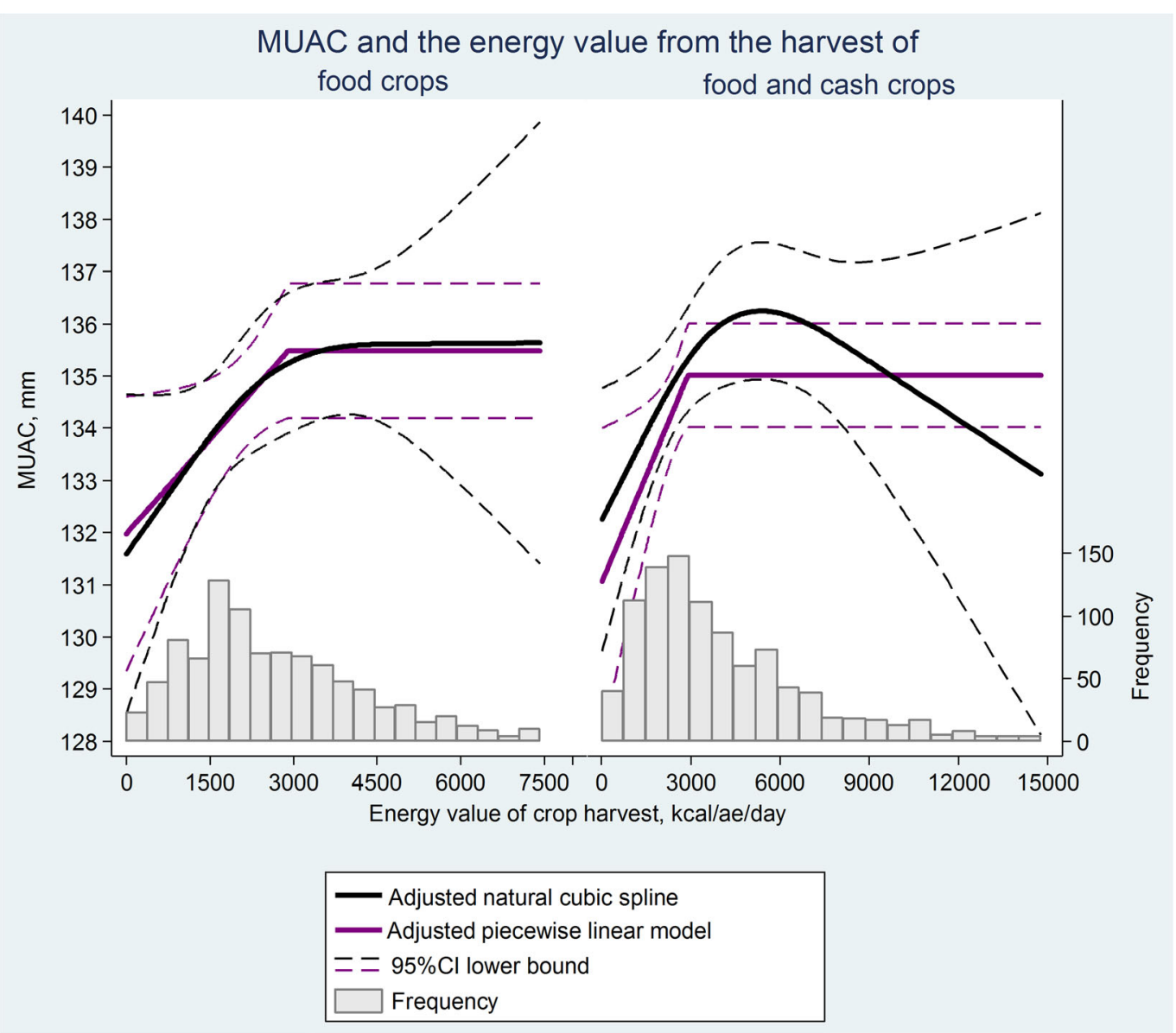

Fig. 3 Restricted natural cubic spline and piecewise linear models of the associations of children's MUAC with food energy production. On the left: food energy estimates are based on food crop harvest alone. On the right: food energy estimates are based on food and cash crop harvest combined.

Abbreviations: $\mathrm{Cl}$, confidence interval; kcal/ae/d, kilocalories per adult equivalent per day; MUAC, middle-upper arm circumference; HDSS, Health and Demographic Surveillance System. Note 1: For purposes of clarity in the visual presentation, we excluded from the models the sparse observations at the highest exposure values: 40 observations excluded within 8000-16,052 kcal/ae/day interval of the energy production from food crop harvest and 14 observations were excluded within 15,000-34,064 kcal/ae/day interval of the energy production from both food and cash crops combined. Note 2: Both models were adjusted for age, sex, month of MUAC measurement, household wealth, non-agricultural occupation, garden produce, village infrastructure, and market presence

Table 2 Estimated differences in MUAC ( $\mathrm{mm}$ ) per difference in food energy production from crop harvest

\begin{tabular}{|c|c|c|c|c|}
\hline \multirow{2}{*}{ Model adjustments } & \multicolumn{2}{|c|}{$\begin{array}{l}\text { Reduction in MUAC }(95 \% \mathrm{Cl}) \text { at } \\
3000 \text { vs } 1000 \mathrm{kcal} / \mathrm{ae} / \mathrm{d}^{\mathrm{a}} \text { : }\end{array}$} & \multicolumn{2}{|c|}{$\begin{array}{l}\text { Reduction in MUAC (95\% Cl) for a } \\
1000 \mathrm{kcal} / \mathrm{ae} / \mathrm{d} \text { decline in crop } \\
\text { harvest below } 2900 \mathrm{kcal} / \mathrm{ae} / \mathrm{d}^{\mathrm{b}} \text { : }\end{array}$} \\
\hline & $\begin{array}{l}\text { Food crop } \\
\text { harvest alone }\end{array}$ & $\begin{array}{l}\text { Food \& cash crop } \\
\text { harvest combined }\end{array}$ & $\begin{array}{l}\text { Food crop } \\
\text { harvest alone }\end{array}$ & $\begin{array}{l}\text { Food \& cash crop } \\
\text { harvest combined }\end{array}$ \\
\hline Model 1: unadjusted & $2.44(0.14,4.73)$ & $2.01(0.12,3.90)$ & $1.27(-0.01,2.55)$ & $1.64(0.22,3.05)$ \\
\hline $\begin{array}{l}\text { Model 2: adjusted for children's age, sex, and month of } \\
\text { MUAC measurement }\end{array}$ & $2.67(0.58,4.76)$ & $1.98(0.26,3.71)$ & $1.44(-0.27,2.60)$ & $1.57(0.29,2.85)$ \\
\hline $\begin{array}{l}\text { Model 3: model } 2+\text { adjustments for household wealth, } \\
\text { non-agricultural occupation, garden produce, village } \\
\text { infrastructure, and market presence }\end{array}$ & $2.49(0.45,4.52)$ & $1.99(0.27,3.69)$ & $1.29(0.15,2.42)$ & $1.55(0.30,2.81)$ \\
\hline $\begin{array}{l}\text { Model 4: model } 3 \text { + adjustment for failure to harvest at } \\
\text { least one of the cultivated crops }\end{array}$ & $2.49(0.46,4.53)$ & $1.97(0.26,3.67)$ & $1.29(0.15,2.43)$ & $1.57(0.31,2.83)$ \\
\hline
\end{tabular}

Abbreviations: $\mathrm{Cl}$ confidence interval, MUAC middle-upper arm circumference, $\mathrm{kcal} / \mathrm{ae} / \mathrm{d}$, kilocalories per adult equivalent per day ${ }^{a}$ Estimates based on models with natural cubic splines

${ }^{\mathrm{b}}$ Estimates based on piecewise linear models 
Table 3 Adjusted estimates of differences in MUAC ( $\mathrm{mm}$ ) per specified difference in food energy production from crop harvest by sex

\begin{tabular}{|c|c|c|c|c|c|c|c|c|}
\hline \multirow[t]{2}{*}{ Sex } & \multirow[t]{2}{*}{ No. (\%) } & \multirow{2}{*}{$\begin{array}{l}\text { Mean MUAC, } \\
\quad \mathrm{mm}\end{array}$} & \multirow{2}{*}{$\begin{array}{l}\text { Mean food energy } \\
\text { from food crop } \\
\text { harvest, kcal/ae/d }\end{array}$} & \multicolumn{2}{|c|}{$\begin{array}{l}\text { Difference in MUAC (95\% Cl): } \\
3000 \text { vs } 1000 \mathrm{kcal} / \mathrm{ae} / \mathrm{d}^{\mathrm{a}}\end{array}$} & \multicolumn{2}{|c|}{$\begin{array}{l}\text { Reduction in MUAC }(95 \% \mathrm{Cl}) \text { for } \\
\text { a } 1000 \mathrm{kcal} / \mathrm{ae} / \mathrm{d} \text { decline in crop } \\
\text { harvest below } 2900 \mathrm{kcal} / \mathrm{ae} / \mathrm{d}^{\mathrm{b}} \text { : }\end{array}$} & \multirow[b]{2}{*}{$\begin{array}{l}p \text {-value for } \\
\text { interaction }^{c}\end{array}$} \\
\hline & & & & $\begin{array}{l}\text { Food crop } \\
\text { harvest alone }\end{array}$ & $\begin{array}{l}\text { Food \& cash crop } \\
\text { harvest combined }\end{array}$ & $\begin{array}{l}\text { Food crop } \\
\text { harvest alone }\end{array}$ & $\begin{array}{l}\text { Food \& cash crop } \\
\text { harvest combined }\end{array}$ & \\
\hline All children & $975(100)$ & 135 & 2978 & $2.49(0.45,4.52)$ & $1.99(0.27,3.69)$ & $1.29(0.15,2.42)$ & $1.55(0.30,2.81)$ & \\
\hline Boys & $499(51)$ & 136 & 3094 & $3.81(0.84,6.77)$ & $3.47(0.97,5.96)$ & $2.15(0.49,3.80)$ & $2.43(0.56,4.30)$ & 0.203 \\
\hline Girls & $476(49)$ & 133 & 2842 & $0.99(-1.81,3.78)$ & $0.86(-2.13,2.57)$ & $0.42(-1.14,1.99)$ & $0.69(-1.02,2.40)$ & \\
\hline
\end{tabular}

Abbreviations: $\mathrm{Cl}$ confidence interval, MUAC middle-upper arm circumference, kcal/ae/d kilocalories per adult equivalent per day, LRT likelihood ratio test ${ }^{\mathrm{a} E s t i m a t e s}$ based on models with natural cubic splines

${ }^{\mathrm{b}}$ Estimates based on piecewise linear models

${ }^{c} p$-value presented for the LRT of interaction applied to the piecewise model with the exposure of food energy from food crop production

energy estimates were based on cereal food crop production alone $\left(\mathrm{E}_{\mathrm{f}}\right)$, and $3.47(95 \% \mathrm{CI} 0.97,5.96) \mathrm{mm}$ less when food energy estimates were based on food and cash crop production combined $\left(\mathrm{E}_{\mathrm{fc}}\right)$. The corresponding figures for girls were $0.99(95 \% \mathrm{CI}-1.81,3.78) \mathrm{mm}$, and 0.86 (95\% CI $-2.13,2.57) \mathrm{mm}$.

In line with these results, Additional file 1: Table S3 shows that the prevalence of acute undernutrition (MUAC $<125 \mathrm{~mm}$ ) was slightly higher in households with $\leq 2900 \mathrm{kcal} / \mathrm{ae} / \mathrm{d}$ food cereal crop energy production. Such households also had lower diversity of crops (as reflected in the number of different crops harvested) and they less frequently produced cash crops and garden produce. Their household size was slightly larger, and they more frequently had at least one member of their household involved in a non-agricultural occupation.

\section{Discussion}

This is one of the few studies examining the association of children's nutritional status with household cereal crop production. Its results suggest that low household production of food energy from cereal crops is associated with lower MUAC for children $\leq 5$ years of age.

The results of the restricted spline plot suggest a decline in MUAC below around $3000 \mathrm{kcal} / \mathrm{ae} / \mathrm{d}$, which is broadly consistent with the recommended energy intake of $2900 \mathrm{kcal} / \mathrm{d}$ for a moderately active man of 30-60 years of age $[51,52]$. The results of the linear spline model show a statistically significant decline in MUAC very similar in gradient to that of the restricted spline plot when the change point was fixed a priori at $2900 \mathrm{kcal} / \mathrm{ae} / \mathrm{d}$.

Our findings are consistent with some [22-24] but not all $[20,21]$ studies examining the association between children's nutritional status and household level measures of agricultural production. Variation in findings across different studies may be explained by different contexts [20], choice of nutritional status measures and temporality of their association with crop harvest (e.g., acute $v s$ chronic undernutrition [20]), and other modifying factors.

We did not find clear evidence of a gender difference in the association of crop production with children's nutritional status. Our findings suggest possibly more pronounced association among boys than girls. This could in part be related to the higher level of child undernutrition among boys than girls in our setting [57]. Given the relatively small study sample, we cannot conclude a difference, but the point estimates were larger in boys than girls.

The current study was conducted in a population whose livelihood is likely to be particularly vulnerable to crop failure and low cereal crop productivity. Over a half of the examined children lived in households whose food crop production in the year 2009 was not sufficient to meet their energy needs for even light activity. A quarter of households would not be able to reach their energy requirements for light activity levels even when selling all their cash crops and purchasing millet instead. The association between low levels of household crop harvest and acute child undernutrition is highly plausible in such context.

We must note that the MUAC measurements analysed in this study were made in the six nutritionally more challenging months of the year in the study area, as they include the period when household cereal stocks from the last harvest start to run low (the time often referred to as the 'lean' or the 'hunger' season) [58]. Analysis of MUAC data collected evenly throughout the year may yield a lower magnitude of the examined association.

The high proportion (14\%) of acute undernutrition among children in our study population is of serious public health significance, according to the guidelines of the World Health Organization (WHO) [59]. The prevalence of acute undernutrition above $10 \%$ is not uncommon in many low- and middle-income countries in Africa, South and South-East Asia [60]. Similar analyses of the association between household crop production and children's nutritional status in other countries of these regions would help identifying whether household crop production levels in these settings also incur risk for their children's nutritional health.

Our study population and similar populations may be vulnerable to the adverse effects of climate change on agricultural productivity. Given that the association between children's nutritional status and 
household crop harvest was identified even in a year of average agricultural productivity and given the evidence of the link between weather-related areawide crop failures with negative nutritional outcomes among children in similar settings [30, 31, 61-66], it is likely that the Nouna HDSS population would experience greater levels of acute child undernutrition in years of low agricultural productivity. Droughts are already recognised as the top natural disaster in Burkina Faso and their frequency and severity is projected to increase with climate change, potentially leading to increased episodes of low crop yields [67-69].

However, our estimates were based on harvest differences across households in a single year with average crop productivity. According to Annual National Agricultural Survey data, over the five years preceding our examined harvest year in the Kossi province did not fall below the average yield level calculated over the period of 1984-2014 [70]. Therefore, our estimated magnitude of change in children's MUAC per difference in food energy from household crop harvest is applicable to average yield levels, and hence, should not be used to infer the possible change in children's MUAC in response to interannual changes in household harvest, particularly those resulting from drought or other exogenous shocks. However, the identified association in a year of average crop productivity does suggest the likely vulnerability of our study population to weatherrelated and other declines in crop yield.

We used the indirect measure of food energy production from crop harvest to approximate household food energy availability. Our measure did not take into account other food sources possibly acquired by households (e.g., food purchases, gifts, and loans [71]) or disposal of the produce (e.g., transfers to others and food waste). Apart from household food energy availability, children's food intake is subject to intra-household food distribution and children's food preferences; children's nutritional status, apart from food intake, is also determined by their health condition and other factors [4]. Furthermore, we used household harvest data reported by the household head. In the socio-cultural context of our study, the household head is the key informant on the amount of the household's crop harvest. However, reported data (as opposed to quality controlled measurements or observations made by data collectors, which in our study area were not available) may have some inconsistencies.

In our analyses, it was not possible to account for crop harvest households produced in years preceding or following the year 2009, as there were no data collected. Such information could help adjusting for any effect of crop harvest on children's MUAC prior to the year 2009 and for any cereal stock remaining from a preceding year that households could consume in addition to the crops harvested in the year 2009 . However, differences in child MUAC in the year 2010 related to household crop harvest in years preceding 2009, if any present at all, would be minor, as MUAC is sensitive to short-term changes in food intake. The influence of previous harvests on our examined MUAC measurements was likely to have been superseded by the influence of the harvest of the year 2009. The harvest of 2010 could have some influence on food intake in August 2010, if any of the households started the harvest of 2010 earlier than September, as assumed in our analyses. This was also impossible to account for due to the lack of information on when individual households started their harvest in the year 2010 .

Other minor limitations include: (1) our adult equivalent calculations were based on the number of household members at the time of the harvest of 2009, and hence, did not account for any possible changes in household composition between the harvest time and the time of child MUAC measurement (March-August 2010), (2) food price estimates were based on a single time point (December 2009, when crop sales occur frequently) for the Nouna market, as the largest market in the study area [72], hence, we did not account for any fluctuations in food price across the year.

\section{Conclusion}

MUAC measurements made during the months of March-August following a 'normal' harvest year, indicate negative impacts of low household cereal crop yields on child nutrition in this rural subsistence farming population of Burkina Faso.

The results suggest that this and similar populations may be adversely affected by low levels of crop harvest and vulnerable to the adverse effects of weather and other factors on household crop yields, especially in the context of climate change. Nutrition-sensitive monitoring of household crop yields and support provision to the most vulnerable households in such settings could aid the achievement of the SDG No. 2 in the face of the projected climate change impacts on agricultural productivity.

\section{Additional file}

Additional file 1: (1) Note on study subject representativeness, (2) Sensitivity Analysis I: exclusion of observations with high crop production values, (3) Characteristics of study population in relation to food energy production from food crops. (DOCX $44.8 \mathrm{~kb}$ ) 


\section{Abbreviations}

AIC: Akaike information criterion; CRSN: Centre de Recherche en Santé de Nouna; $E_{f}$ Energy value of average daily household food cereal crop produce; $E_{f c}$ : Energy value of average daily household food and cash crop produce combined; HDSS: Health and demographic surveillance system; IQR: Interquartile range; kcal/ae/d: Kilocalories per adult equivalent per day; LR: Likelihood ratio; MUAC: Middle-upper arm circumference; SDG: Sustainable Development Goal; SOFITEX: Societé Burkinabé des Fibres et Textiles; WHO: World Health Organization

\section{Acknowledgements}

Authors would like to thank Professor Ben Armstrong for advice on statistical analyses, Dr. Alan Dangour and Dr. Rosemary Green for advice on the link between agriculture and nutrition, and Dr. Marko Kerac for advice on the measure of the middle-upper arm circumference, the staff of the Centre de Recherche en Santé de Nouna for the collection and provision of the data used in this study, and Moubassira Kagoné, Pascal Zabré, Dr. Issouf Traoré, and Cheik Bagagnan for explanations on the data structure.

\section{Funding}

This work was supported by the Natural Environment Research Council (grant number NE/L501979/1). Funder had no contribution to the study design, conduct of the study, analysis of data, interpretation of findings or the preparation of the manuscript.

\section{Availability of data and materials}

The data that support the findings of this study was collected and provided by the Centre de Recherche en Santé de Nouna and should be requested from the Centre de Recherche en Santé de Nouna.

\section{Authors' contributions}

KB designed the study with advisory input from PW and RS; AS provided data; KB cleaned and prepared data; KB analysed data with advice from PW and AG; KB drafted the paper with editorial changes and comments from other authors. All authors approved the final manuscript.

\section{Competing interests}

The authors declare that they have no competing interests.

\section{Consent for publication}

Not applicable.

\section{Ethics approval and consent to participate}

This study was conducted according to the guidelines laid down in the Declaration of Helsinki and all procedures were approved by the London School of Hygiene and Tropical Medicine Observational Ethics Committee and the Comité Institutionnel d'Ethique du Centre de Recherche en Santé de Nouna. Verbal informed consent, selected as a standard in Nouna Health and Demographic Surveillance System in agreement between the local community and Centre de Recherche en Santé de Nouna, was obtained from all subjects/patients.

\section{Publisher's Note}

Springer Nature remains neutral with regard to jurisdictional claims in published maps and institutional affiliations.

\section{Author details}

'Department of Social and Environmental Health Research, London School of Hygiene \& Tropical Medicine, 15-17 Tavistock Place, London WC1H 9SH, UK. ${ }^{2}$ Centre de Recherche en Santé de Nouna, Rue Namory Keïta, Nouna, Kossi province, Boucle du Mouhoun region, Burkina Faso. ${ }^{3}$ Institute of Public Health, Heidelberg University, Im Neuenheimer Feld, Heidelberg 324 69120, Germany.
Received: 23 August 2016 Accepted: 11 May 2017

Published online: 20 June 2017

\section{References}

1. UN Sustainable Development Platform. Sustainable Development Goals. 2015. https://sustainabledevelopment.un.org/topics. Accessed 21 Nov 2015.

2. Gillespie S, Haddad L, Mannar V, Menon P, Nisbett N. The politics of reducing malnutrition: Building commitment and accelerating progress. Lancet. 2013;382:552-69.

3. Bhutta ZA, Chopra M, Axelson H, Berman P, Boerma T, Bryce J, et al. Countdown to 2015 decade report (2000-10): taking stock of maternal, newborn, and child survival. Lancet. 2010:375:2032-44.

4. Black RE, Allen LH, Bhutta ZA, Caulfield LE, de Onis M, Ezzati M, et al. Maternal and child undernutrition: global and regional exposures and health consequences. Lancet. 2008;371:243-60.

5. WHO. Children: reducing mortality. 2016. http://www.who.int/mediacentre/ factsheets/fs178/en/. Accessed 4 Mar 2016.

6. Dercon S, Porter C. Live aid revisited: Long-term impacts of the 1984 Ethiopian famine on children. J Eur Econ Assoc. 2014;12:927-48.

7. Black RE, Victora CG, Walker SP, Bhutta ZA, Christian P, de Onis M, et al. Maternal and child undernutrition and overweight in low-income and middle-income countries. Lancet. 2013;382:427-51.

8. Dewey KG, Begum K. Long-term consequences of stunting in early life. Matern Child Nutr. 2011;7:5-18.

9. Ampaabeng SK, Tan CM. The long-term cognitive consequences of early childhood malnutrition: the case of famine in Ghana. J Health Econ. 2013;32:1013-27.

10. UN. The Millennium development goals report. United Nations. 2015. https://visit.un.org/millenniumgoals/2008highlevel/pdf/MDG_Report_2008_ Addendum.pdf. Accessed 4 Mar 2016

11. Lloyd SJ, Kovats SR, Chalabi Z. Climate change, crop yields, and undernutrition: development of a model to quantify the impact of climate scenarios on child undernutrition. Environ Health Perspect. 2011;119:1817-23.

12. Nelson GC, Rosegrant MW, Palazzo A, Gray I, Ingersoll C, Robertson R, et al. Food security farming and climate change to 2050. IFPRI: Washington; 2010

13. Nelson GC, Rosegrant M, Koo J, Robertson R, Sulser T, Zhu T, et al. Climate change: impact on agriculture and costs of adaptation. IFPRI: Washington; 2009.

14. Parry M, Evans A, Rosegrant MW, Wheeler TR. Climate change and hunger: responding to the challenge. Rome: World Food Programme; 2009

15. Schmidhuber J, Tubiello FN. Global food security under climate change. Proc Natl Acad Sci. 2007;104:19703-8.

16. Springmann M, Mason-D'Croz D, Robinson S, Garnett T, Godfray HCJ, Gollin $D$, et al. Global and regional health effects of future food production under climate change: a modelling study. Lancet. 2016;6736:1-10.

17. Ruel MT, Alderman H. Nutrition-sensitive interventions and programmes: how can they help to accelerate progress in improving maternal and child nutrition? Lancet. 2013;382:536-51.

18. FAO. An introduction to the basic concepts of food security. Food Security Information for Action Practical Guide. 2008. http://www.fao.org/docrep/ 013/al936e/al936e00.pdf. Accessed 13 May 2017.

19. Kaufmann S. The nutrition situation in Northern Laos - determinants of malnutrition and changes after four years of intensive interventions. PhD thesis. Giessen: Justus Liebig University Giessen; 2008.

20. Shack KW, Grivetti LE, Dewey KG. Cash cropping, subsistence agriculture, and nutritional status among mothers and children in lowland Papua New Guinea. Soc Sci Med. 1990:31:61-8.

21. Ghattas H, Barbour JM, Nord M, Zurayk R, Sahyoun NR. Household food security is associated with agricultural livelihoods and diet quality in a marginalized community of rural Bedouins in Lebanon. J Nutr. 2013;143:1666-71

22. Dorsey JL, Manohar S, Neupane S, Shrestha B, Klemm RDW, West KP. Individual, household, and community level risk factors of stunting in children younger than 5 years: Findings from a national surveillance system in Nepal. Matern Child Nutr. 2017;1-16.

23. Girard AW, Self JL, McAuliffe C, Olude O. The effects of household food production strategies on the health and nutrition outcomes of women and young children: A systematic review. Paediatr Perinat Epidemiol. 2012;26:205-22. 
24. Yamano T, Alderman H, Christiaensen L. Child growth, shocks, and food aid in Rural Ethiopia. Am J Agric Econ. 2005;87:273-88.

25. Grace K, Nagle NN, Husak G. Can small-scale agricultural production improve children's health? Examining stunting vulnerability among very young children in Mali, West Africa. Ann Am Assoc Geogr. 2016;4452:1-16.

26. Maxwell DG. Alternative food security strategy: A household analysis of urban agriculture in Kampala. World Dev. 1995;23:1669-81.

27. Maxwell D, Levin C, Csete J. Does urban agriculture help prevent malnutrition? Evidence from Kampala. Food Policy. 1998;23:411-24.

28. Muller I, Vounatsou P, Allen BJ, Smith T. Spatial patterns of child growth in Papua New Guinea and their relation to environment, diet, socio-economic status and subsistence activities. Ann Hum Biol. 2001;28:263-80

29. Brentlinger PE, Hernan MA, Hernandez-Diaz S, Azaroff LS, McCall M. Childhood malnutrition and postwar reconstruction in rural El Salvador. A community-based survey. J Am Med Assoc. 1999;281:184-90.

30. Akresh R, Verwimp P, Bundervoet T. Civil war, crop failure, and child stunting in Rwanda. Econ Dev Cult Change. 2011;59:777-810.

31. Hoddinott J, Kinsey B. Child growth in the time of drought. Oxf Bull Econ Stat. 2001;63:409-36.

32. UNDP (United Nations Development Program). Human development report - 2009 overcoming barriers: human mobility and development. New York: Palgrave Macmillan. p. 2009.

33. Central Intelligence Agency. The world factbook: Burkina Faso. 2013. https:// www.cia.gov/library/publications/the-world-factbook/geos/uv.html. Accessed 5 March 2017.

34. Indepth. Nouna HDSS, Burkina Faso. 2009. http://www.indepth-network.org/ Profiles/Nouna\%20HDSS.pdf. Accessed 13 May 2017.

35. Dabat M, Zongo I, Kiendrebeogo R. Etude sur les relations entre marchés et sécurité alimentaire au Burkina Faso. World Food Program. 2012. http:// agritrop.cirad.fr/562477/. Accessed 13 May 2017.

36. Chauvin ND, Mulangu F, Porto G. food production and consumption trends in Sub-Saharan Africa: prospects for the transformation of the agricultural sector. 2012. http://www.undp.org/content/dam/rba/docs/ Working\%20Papers/Food\%20Production\%20and\%20Consumption.pdf. Accessed 12 Apr 2016.

37. INSD. Population et densité par région et province. 2013. http://www.insd. bf/n/contenu/Tableaux/T0316.htm. Accessed 4 Mar 2016.

38. CRSN. Manuel de l'enquêteur: Enquête Ménage N¹2. 2011.

39. Beiersmann C, Bountogo M, Tiendrébeogo J, Louis VR, Gabrysch S, Yé $M$, et al. Malnutrition in young children of rural Burkina Faso: comparison of survey data from 1999 with 2009. Tropical Med Int Health. 2012;17:715-21.

40. Mwangome MK, Fegan G, Fulford T, Prentice AM, Berkley JA. Mid-upper arm circumference at age of routine infant vaccination to identify infants at elevated risk of death: a retrospective cohort study in the Gambia. Bull World Health Organ. 2012;90:887-94.

41. Myatt M. Plausible/extreme values for MUAC. En-Net 2010. http://www.ennet.org/question/233.aspx. Accessed 13 Feb 2017.

42. Ralston ME, Myatt MA. Weight estimation tool for children aged 6 to 59 Months in Limited-Resource Settings. PLoS One. 2016;11:e0159260.

43. Binns P, Dale N, Hoq M, Banda C, Myatt M. Relationship between mid upper arm circumference and weight changes in children aged 6-59 months. Archives of Public Health. 2015;73:54.

44. World Health Organization, United Nations Childrens Fund. WHO child growth standards and the identification of severe acute malnutrition in infants and children. Geneva: World Health Organization; 2009.

45. Laillou A, Prak S, De Groot R, Whitney S, Conkle J, Horton L, et al. Optimal screening of children with acute malnutrition requires a change in current WHO guidelines as MUAC and WHZ identify different patient groups. PLoS One. 2014:9:9-15.

46. Grellety E, Krause LK, Shams Eldin M, Porten K, Isanaka S. Comparison of weightfor-height and mid-upper arm circumference (MUAC) in a therapeutic feeding programme in South Sudan: is MUAC alone a sufficient criterion for admission of children at high risk of mortality? Public Health Nutr. 2015;18:2575-81.

47. Myatt M, Khara T, Collins S, Myatt M, Khara T, Collins S, et al. A review of methods to detect cases of severely malnourished children in the community for their admission into community-based therapeutic care programs. Food Nutr Bull. 2006;27:S7-23.

48. Stadlmayr B, Charrondiere UR, Enujiugha VN, Bayili RG, Fagbohoun EG, Samb B, et al. West African food composition table. Rome: FAO; 2012.
49. Guissou R, Ilboudo F. Analyse Des Incitations Et Pénalisations Pour Le Maïs Au Burkina Faso. Rome; 2012. http://www.fao.org/3/a-at463f.pdf. Accessed 4 Mar 2016.

50. SOFITEX. Evolution du prix du coton graine. 2011. http://www.sofitex.bf/ graphique/prixcg.php. Accessed 4 Mar 2016.

51. FAO/WHO/UNU. Human energy requirements: Report of a Joint FAO/WHO/ UNU Expert Consultation. FAO Food Nutr. Tech. Rep. Ser. 2001.

52. Smith LC, Subandoro A. Measuring food security using household expenditure surveys. 2007. http://www.ifpri.org/publication/measuringfood-security-using-household-expenditure-surveys. Accessed 4 Mar 2016.

53. Schoeps A, Souares A, Niamba L, Diboulo E, Kynast-Wolf G, Müller O, et al. Childhood mortality and its association with household wealth in rural and semi-urban Burkina Faso. Trans R Soc Trop Med Hyg. 2014;108:639-47.

54. Harrell FE. Regression modeling strategies. With applications to linear models, logistic regression, and survival analysis. New York: Springer; 2001.

55. Phalkey RK, Aranda-Jan C, Marx S, Höfle B, Sauerborn R. Systematic review of current efforts to quantify the impacts of climate change on undernutrition. Proc Natl Acad Sci. 2015;112:E4522-9.

56. StataCorp. Stata statistical software: release 14.1. College Station, TX: StataCorp LP; 2015.

57. Beiersmann C, Bermejo Lorenzo J, Bountogo M, Tiendrébeogo J, Gabrysch $S$, Yé $M$, et al. Malnutrition determinants in young children from Burkina Faso. J Trop Pediatr. 2013;59:372-9.

58. FEWS NET. Seasonal Calendar: Typical Year. 2013. Available from: http:// www.fews.net/west-africa/burkina-faso/seasonal-calendar/december-2013. Accessed 1 Jan 2016.

59. WHO. Nutritional landscape information system: country profile indicators: interpretation guide. Geneva: WHO; 2010.

60. World Bank. Prevalence of wasting, weight for height (\% of children under 5). 2015. http://data.worldbank.org/indicator/ST.INT.ARVL/countries?display= default. Accessed 10 Apr 2016

61. Chotard S, Mason JB, Oliphant NP, Mebrahtu S, Hailey P. Fluctuations in wasting in vulnerable child populations in the greater horn of Africa. Food Nutr Bull. 2010;31:S219-33.

62. Woldehanna T. Do pre-natal and post-natal economic shocks have a longlasting effect on the height of 5-year-old children? Oxford: Young Lives; 2010.

63. Kumar S, Bhawani L. Managing child malnutrition in a drought affected district of Rajasthan-a case study. Indian J Public Health. 2005;49:198-206.

64. Dercon S, Hoddinott J. Health, shocks, and poverty persistence. In: Decron, S, Insur. Against Poverty. 2005. http://www.rrojasdatabank.info/DercHodd. pdf. Accessed: 4 Mar 2016.

65. Alderman $\mathrm{H}$, Hoddinott J, Kinsey B. Long term consequences of early childhood malnutrition. Oxf Econ Pap. 2006;58:450-74.

66. Omitsu M, Yamano T. The impacts of hurricane mitch on child health: evidence from Nicaragua. Int. Assoc. Agric. Econ. Conf. 2006; http:// ageconsearch.umn.edu/bitstream/25700/1/pp060380.pdf. Accessed 4 Mar 2016.

67. Field C, Barros V, Stocker T, Dahe Q, editors. Managing the risks of extreme events and disasters to advance climate change adaptation: special report of the intergovernmental panel on climate change. Cambridge: Cambridge University Press; 2012.

68. Brown O, Crawford A. Assessing the security implications of climate change for West Africa: Country case studies of Ghana and Burkina Faso. IISD: Manitoba; 2008

69. Ministaire de L'Environnement et du Cadre de Vie: Secretariat Permanent du Conseil National pour L'Environnement et le Developpement Durable. Programme d'Action National d'Adaptation a le Variabilite et aux Changements Climatiques (PANA du Burkina Burkina Faso). Ouagadougou: Ministère de L'Environnement et du Cadre de Vie; 2007.

70. Ministere de l'Agriculture de l'Hydraulique et des Ressources Halieutiques: Secretariat General: Direction de la Prospective et des Statistiques Agricoles et Alimentaires (DPSAA). Resultats Definitifs de l'Enquete Permanente Agricole (EPA). Ouagadougou: Ministere de I'Agriculture de I'Hydraulique et des Ressources Halieutiques; 2011.

71. Sauerborn R, Adams A, Hien M. Household strategies to cope with the economic costs of illness. Soc Sci Med. 1996;43:291-301.

72. Rongead. Le Sésame au Burkina Faso: Etat des lieux 2013 marches du sésame et commercialisation. 2013. http://www.rongead.org/IMG/pdf/5_ sesame_web.pdf. Accessed 13 May 2017. 